INTERNATIONAL JOURNAL OF RESEARCHES IN BIOSCIENCES, AGRICULTURE AND TECHNOLOGY (c) VISHWASHANTI MULTIPURPOSE SOCIETY (G lobal Peace Multipurpose Society) R. No.MH-659/13(N) www.vmsindia.org

\title{
EFFECT OFTHRESHING, DRYING AND STORAGE METHODS ON SEED QUALITY OF MOTHBEAN
}

\author{
Rajesh Gadewar ${ }^{1}$, Ashish Lambat ${ }^{2}$, Vipin Babhulkar ${ }^{3}$, Prachi Lambat ${ }^{4}$, \\ Sanjiv Charjan ${ }^{5}$ and Ramesh Parate ${ }^{6}$ \\ 3,5,6 College of Agriculture (Dr. PDKV's) Nagpur. \\ 1,2, Se vadal Mahila Mahavidyalaya and Research Academy,Nagpur(MS) \\ ${ }^{4}$ Shri Mathuradas Mohata Science College, Nagpur
}

\begin{abstract}
:
Effects of Threshing, drying and storage methods on seed quality of Moth bean were studied. The seeds threshed by hand had maintained significantly very low mechanical damage to seeds and higher germination, seedling vigour and field emergence percentage. Drying of Mothbean seeds at lower temperature (shade) recorded significantly higher germination, seedling vigour and field eme rgence percentage. The mung seeds stored in polyethylene bags re corded significantly higher germination, seedling vigour and field emergence and lesser seed invasion by fungal flora during storage as compared to jute and cloth bags under ambient condition. It was also noted that Altrnaria sp., Aspergillus sp., Fusarium sp., Rhizopus sp., Tricothecium sp. And Penicillium sp. Were the most commonly occurring fungi irrespective of storage pe riods and storage containers during storage under ambient condition.
\end{abstract}

Keywords: Mothbean, seed quality, threshing, drying, container, storage.

\section{Introduction:}

Moth bean is a rich source of protein but it is yet to gain impetus in our country. One of the major problems encountered in urdbean production in India is the lack of good quality seeds. Seed yield and its quality depend on a number of factors. The time of harvesting, methods of threshing, drying and storage of seeds are among the major consideration in deciding the seed quality and productivity. Seed quality may be impaired while the seeds are still on mother plant (Pullock, 1972) Physiomorphological and physiological changes might set in, if the seeds are retained on the mother plant for a longer duration beyond physiological maturity (Ovchrov and Kizilova, 1966). Dharmalingam and Basu (1988) reported that the seed harvested at physiological maturity had highest germination and vigour than those harvested at premature. Sangakkara and Wanisekera (1990) reported that the mungbean seed quality not affected by hand threshing, drying at low temperature and storing the seeds in polyethylene bags in low temperature and relative humidity. As very little information is available on this aspect, hence an experiment was planned to study the effect of post harvest operations on seed quality of Mothbean.

\section{Material and Methods:}

Plants of Mothbean (Variety MBS-27) we re harvested at physiological maturity (i.e. when green pod turns in blackish green in colour) by cutting to a height of $5 \mathrm{~cm}$ from ground level. Pods were removed from the harvested plants and dried on the threshing floor as per usual method of drying. The harvested pods were divided in to 5 lots. First lot was threshed by hand, $2^{\text {nd }}$ by stick beating 3 rd by machine threshed $300 \mathrm{rpm}$. $4^{\text {th }}$ by $400 \mathrm{rpm}$ and $5^{\text {th }}$ by $500 \mathrm{rpm}$ separately. Half threshed seeds of each threshing methods dried in the sun and remaining half thre shed seed was dried in the sun and remaining half threshed seed was dried in shade. Three days were required for sun drying and 10 days we re required for shade drying to reach safe moisture content level(10 \pm $1 \%)$. The thre shed and dried seeds by different methods were kept in jute, cloth and polyethylene bags of $178 \mathrm{um}$ of size $20 \mathrm{~cm} \mathrm{x}$ $30 \mathrm{~cm}$ respectively of $1 \mathrm{Kg}$ each and stored in wire - mesh almirah in masonry building having cemented wall, roof and floor under ambient condition for 9 months. The observations on moisture content and germination tests was conducted as prescribed in International rules for seed testing (ISTA, 1985). Two hundred seeds were used to isolate fungi following standard blotter and agar plate methods (ISTA,1976). The seedling vigour index was worked out following the method of Aldul Baki \& Anderson (1973). For filed emergence test, sowing of mung seeds was done in randomized block design, with four replications with inter and intra-row spacing of 1 feet and 6 inches respectively. Observations for field emergence were recorded daily and finally the established seedlings were counted after one month of sowing. The experimental data was statistically scrutinized by random bloc design as per Panse and Sukhatme (1967).

\section{Result and Discussion:}

Data presented in the Table 1 showed that machine threshed at $500 \mathrm{rpm}$ results into seeds 
with significantly maximum mechanical damage (3.2\%) which is followed by $400 \mathrm{rpm}(2.6 \%) 300$ $\operatorname{rpm}(1.6 \%)$, stick beating $(1.4 \%)$, and hand threshed (0.3\%). Saini et al. (1982), Sangakkara and Wanisekera (1990) reported that the seed threshed by hand lower mechanical damage to seed coat than machine threshed.

In was observed form the Table 1 that the germination percentage of Mothbean seeds threshed by different methods varies significantly and it was highest in hand threshed seeds (95\%) which was closely followed by stick-beating (91\%), machine threshed 300 $\mathrm{rpm}(84 \%), 400 \mathrm{rpm}(80 \%)$ and $500 \mathrm{rpm} \mathrm{(71 \% ).}$ The germination percentage was decreased with increasing in mechanical damage to the seed coat of mung. It was also observed that the abnormal seedling increases with the increasing the mechanical damage to the seed coat of mung. The similar results also reported by Soesarsano and Copeland (1974), Sangakkara, Waniseke $r$ (1990), and Lambat et al. (2011) Seedling vigour index and filed emergence followed the same trends of ge rmination. It was highest in hand-threshed seeds as compared to other thre shing method.

The effect of seed drying methods for reduction the moisture content to a desirable level is presented in Table 2 . The result suggested that the three $(3)$ days were required for sun drying and ten (10) days required for shade drying to reach safe level of moisture content $(10 \pm 1 \%)$. Study on seed drying indicated that the germination of sundried hand threshed seeds was (87\%) which is closely followed by stick beating (83\%), machinethreshed $300 \mathrm{rpm}$ (80\%), $400 \mathrm{rpm}(78 \%)$ and $500 \mathrm{rpm}(70 \%)$. As against95\% in handthreshed, $90 \%$ in stick beating, $85 \%$ in machine-thre shed $300 \mathrm{rpm} 85 \%$ in $400 \mathrm{rpm}$ and $78 \%$ in $500 \mathrm{rpm}$ in shade dried seeds. In shade drying, low temperature minimizes scorching due to gradual loss of the moisture and there was no adverse effect on germinability of seeds. The result confirms the findings of Philpot, (1976), Patil and Zode, (1993), Lambat et al. (2011). In sun drying, high ambient temperature develop a rapid flow of moisture within the seeds causing stress and sun scorching to the embryo and cotyledons and this results in reduction of germinability with high number of abnormal seedlings and dead seeds. Morrison and Robertson, (1978), Sangakkara and Wanisekera, (1990), Patil and Zode, (1993). Seedling vigour index and field emergence percentage also followed the same trend of germination in mung. Similar results also reported by Saini et al. (1982) Patil and Zode, (1993) and Lambat et al. 2011

The apparent influence of threshing, drying methods and storage containers on germination, seedling vigour index and field emergence percentage of Mothbean seeds during storage presented in Table 3 . The data indicated that the germination, seedling vigour and field emergence percentage of stored Mothbean declined with increasing storage period, however the rate of loss varied with the methods of threshing, drying and types of storage containers used. A sharp declined in germination, seedling vigour index and field emergence occurred in seeds threshed by machine $500 \mathrm{rpm}$, drying in sun and stored in jute, cloth and polyethylene bags during storage. However, there was practically less loss of germination, seedling vigour index and field emergence percentage in seeds threshed by hand dried in shade and stored in jute, cloth and polyethylene bags during storage for 9 months Sangakkara and Wanisekera, (1990), Patil and Zode, (1993) and Lambat et al. (2011) also reported that the sun drying of seeds harmful for germination. In the present study, it was observed that the Mothbean seed, stored in polyethylene bags were undergo the least amount of loss of ge rminability to great extent as compared to jute and cloth bags irrespective to thre shing and drying method Vanangamudi, (1988), Shivankar et al. (1990), Likhitkar and Charjan, (1995) and Lambat et al. (2011) also reported superiority of polyethylene bags over jute and cloth bags for successful carry over of seed during storage. In the present study, the similar tre nds of germination we re observed in seedling vigour index and field emergence percentage of Mothbean seeds during storage.

During this study (Table 4) it was evident that the maximum number of fungal colonies did develops in jute bags which are followed by cloth bags and polytheylene bags during storage. The polyethylene bags provided much protection as polye thylene bags resist moisture penetration which helps in preventing the development of fungal colonies both quantita tive and species wise irrespective eto threshing and drying methods. It was also noted that Alternaria sp., Aspergillus sp. Fusarium sp., Peniculium sp., Rhizopus sp. and Trichothecium $\mathrm{sp}$. were the most commonly occurring fungi irrespective of storage periods and containers. The ge rminability of mung seeds decreased with increase in incidence percentage of fungal flora and storage period. The isolated fungi we re most inhibitory to germination. The result obtained 
were in conformity with the findings of Charjan and Gupta (1996) \& Wankhede et al. (2010) and Lambat et al. (2011). It was also observed that the lower storage potential of mechanical damage seeds threshed by machine and sun dried may be because of higher rate of respiration and attraction of more fungal flora due to higher leaching of sugar which cause early reduction in germination, seedling vigour and field emergence (Burriga, 1961 and Lambat et al 2011)

\section{Conclusion:}

Thus, these results highlight the mainte nance of Mothbean seed quality of sowing purposes in the next sowing reason for getting better yield. The mung pods should be threshed by hand or stick beating and dried in shade upto safe moisture level $(10 \pm 1 \%)$ and stored in polye thylene bags, shows greater germinability, seedling vigour index and filed emergence and lesser invasion by fungal flora upto the next sowing season.

Table 1. Effect of threshing methods on mechanical damage to seed coat, sound seeds and ge rmination percentage in Mothbean

\begin{tabular}{|c|c|c|c|c|c|c|c|c|}
\hline \multirow{2}{*}{$\begin{array}{l}\text { Sr. } \\
\text { No. }\end{array}$} & \multirow{2}{*}{$\begin{array}{l}\text { Threshing } \\
\text { meth ods }\end{array}$} & \multirow{2}{*}{$\begin{array}{l}\text { Mechanically } \\
\text { damaged } \\
\text { seed }(\%)\end{array}$} & \multirow{2}{*}{$\begin{array}{l}\text { Sound } \\
\text { seed } \\
(\%)\end{array}$} & \multicolumn{3}{|c|}{ Germination Analysis \% } & \multirow{2}{*}{$\begin{array}{l}\text { Seedling } \\
\text { Vigour } \\
\text { Index }\end{array}$} & \multirow{2}{*}{$\begin{array}{l}\text { Field } \\
\text { emergence } \\
(\%)\end{array}$} \\
\hline & & & & $\begin{array}{l}\text { Normal } \\
\text { seedling } \\
(\%)\end{array}$ & $\begin{array}{l}\text { Abnor mal } \\
\text { Seedling } \\
(\%)\end{array}$ & $\begin{array}{l}\text { Dead } \\
\text { Seed } \\
(\%)\end{array}$ & & \\
\hline 1 & $\begin{array}{l}\text { Hand - } \\
\text { Threshing }\end{array}$ & 0.2 & 99.8 & 96 & 2 & 2 & 1209 & 88 \\
\hline 2 & $\begin{array}{l}\text { Stick } \\
\text { Beating }\end{array}$ & 103 & 98.6 & 91 & 5 & 4 & 1101 & 82 \\
\hline 3 & $\begin{array}{l}\text { Machine- } \\
\text { Threshing } \\
300 \mathrm{rpm}\end{array}$ & 1.6 & 98.4 & 84 & 12 & 6 & 1090 & 74 \\
\hline 4 & $400 \mathrm{rpm}$ & 2.6 & 97.4 & 80 & 15 & 5 & 911 & 69 \\
\hline \multirow[t]{3}{*}{5} & $500 \mathrm{rpm}$ & 3.2 & 96.8 & 71 & 21 & 8 & 808 & 59 \\
\hline & $\mathrm{SE}(\mathrm{m})+$ & 0.2 & 0.2 & 1.5 & $\mathrm{n} / \mathrm{a}$ & $\mathrm{n} / \mathrm{a}$ & 68 & 1.2 \\
\hline & C.D at $5 \%$ & 0.7 & 0.6 & 4.5 & $\mathrm{n} / \mathrm{a}$ & $\mathrm{n} / \mathrm{a}$ & 206 & 3.7 \\
\hline
\end{tabular}

Table 2 : Effect of th reshing and drying methods on ge rmination pe rcentage, seedling vigour index and field emergence percentage in Mothbean.

\begin{tabular}{|c|c|c|c|c|c|c|c|c|c|c|c|}
\hline \multirow{3}{*}{$\begin{array}{l}\text { Sr. } \\
\text { No }\end{array}$} & \multirow{3}{*}{$\begin{array}{l}\text { Threshing } \\
\text { Methods }\end{array}$} & \multicolumn{5}{|c|}{ Shade drying } & \multicolumn{5}{|c|}{ Sun drying } \\
\hline & & \multicolumn{5}{|c|}{ G.A. $\%$} & \multicolumn{5}{|c|}{ G.A. $\%$} \\
\hline & & NS & ABS & DS & SVI & FE\% & NS & ABS & DS & SVI & FE\% \\
\hline 1 & $\begin{array}{l}\text { Hand - } \\
\text { Threshing }\end{array}$ & 95 & 3 & 2 & 1139 & 87 & 87 & 6 & 7 & 1099 & 78 \\
\hline 2 & Stick Beating & 90 & 6 & 4 & 1003 & 80 & 83 & 10 & 7 & 1001 & 73 \\
\hline 3 & $\begin{array}{l}\text { Machine- } \\
\text { Threshing } \\
300 \mathrm{rpm}\end{array}$ & 85 & 9 & 4 & 979 & 78 & 80 & 14 & 6 & 7979 & 70 \\
\hline 4 & $400 \mathrm{rpm}$ & 83 & 12 & 3 & 882 & 75 & 78 & 17 & 5 & 912 & 67 \\
\hline \multirow[t]{3}{*}{5} & $500 \mathrm{rpm}$ & 78 & 20 & 2 & 814 & 68 & 70 & 19 & 11 & 810 & 58 \\
\hline & $\mathrm{SE}(\mathrm{m}) \pm$ & 1.2 & $\mathrm{~N} / \mathrm{A}$ & $\mathrm{N} / \mathrm{A}$ & 50 & 1.2 & 1.2 & $\mathrm{~N} / \mathrm{A}$ & $\mathrm{N} / \mathrm{A}$ & 55 & 1.3 \\
\hline & C.D at $5 \%$ & 3.7 & $\mathrm{~N} / \mathrm{A}$ & $\mathrm{N} / \mathrm{A}$ & 151 & 3.6 & 3.7 & $\mathrm{~N} / \mathrm{A}$ & $\mathrm{N} / \mathrm{A}$ & 166 & 4.0 \\
\hline & Germination a & & -Norm & Seec & & Ab no & & $\begin{array}{l}\text { ling, D } \\
\text { ean, C }\end{array}$ & $\begin{array}{l}- \text { Dead } \\
\text { at } 5\end{array}$ & $\begin{array}{l}\text { ed, ST } \\
\text { Critica }\end{array}$ & \\
\hline
\end{tabular}


Table 3. Effect of threshing, drying me thods and storage containe rs on germination percentage, seedling vigour ind ex, field eme rgence percentage in Mothbean during storage.

\begin{tabular}{|c|c|c|c|c|c|c|c|}
\hline \multirow[t]{2}{*}{$\begin{array}{l}\text { Sr. } \\
\text { No. }\end{array}$} & \multirow[t]{2}{*}{$\begin{array}{l}\text { Drying Methods/ Packing } \\
\text { Methods }\end{array}$} & \multicolumn{2}{|c|}{ Germination \% } & \multicolumn{2}{|c|}{$\begin{array}{l}\text { Se edling Vigour } \\
\text { Index }\end{array}$} & \multicolumn{2}{|c|}{$\begin{array}{l}\text { Field emergence } \\
\%\end{array}$} \\
\hline & & Initial & $\begin{array}{l}9 \\
\text { Months }\end{array}$ & Initial & 9 Months & Initial & $\begin{array}{l}9 \\
\text { Months }\end{array}$ \\
\hline \multirow[t]{10}{*}{1} & Hand threshed & & & & & & \\
\hline & 1) Shade drying & & & & & & \\
\hline & i) Jute bag & 95 & 89 & 1139 & 901 & 87 & 79 \\
\hline & ii) Cloth bag & 95 & 91 & 1139 & 931 & 87 & 81 \\
\hline & iii) Polyethylene bag & 95 & 93 & 1076 & 1102 & 87 & 83 \\
\hline & 2) Sun drying & & & & & & \\
\hline & i) Jute bag & 87 & 81 & 1099 & 812 & 78 & 71 \\
\hline & ii) Cloth bag & 87 & 81 & 1099 & 812 & 78 & 71 \\
\hline & iii) Polyethylene bag & 87 & 85 & 1099 & 897 & 78 & 75 \\
\hline & $\mathrm{SE}(\mathrm{m})+$ & $\mathrm{N} / \mathrm{A}$ & 2.5 & $\mathrm{~N} / \mathrm{A}$ & 44 & $\mathrm{~N} / \mathrm{A}$ & 2.4 \\
\hline \multirow[t]{9}{*}{2} & Stick beating & & & & & & \\
\hline & 1) Shade drying & & & & & & \\
\hline & i) Jute bag & 90 & 83 & 1003 & 872 & 80 & 66 \\
\hline & ii) Cloth bag & 90 & 81 & 1003 & 821 & 80 & 68 \\
\hline & iii) Polyethylene bag & 90 & 88 & 1003 & 996 & 80 & 75 \\
\hline & $\begin{array}{l}\text { 2) Sun drying } \\
\text { i) Jute bag }\end{array}$ & 83 & 74 & 1001 & 801 & 78 & 63 \\
\hline & ii) Cloth bag & 83 & 75 & 1001 & 792 & 78 & 64 \\
\hline & iii) Polyethylene bag & 83 & 80 & 1001 & 962 & 78 & 70 \\
\hline & $\mathrm{SE}(\mathrm{m})+$ & $\mathrm{N} / \mathrm{A}$ & 2.9 & $\mathrm{~N} / \mathrm{A}$ & 43 & $\mathrm{~N} / \mathrm{A}$ & 3.0 \\
\hline \multirow[t]{10}{*}{3} & $\begin{array}{l}\text { Machine -threshed ( } 300 \\
\text { rpm) }\end{array}$ & & & & & & \\
\hline & 1) Shade drying & & & & & & \\
\hline & i) Jute bag & 85 & 72 & 979 & 840 & 78 & 61 \\
\hline & ii) Cloth bag & 85 & 74 & 979 & 856 & 78 & 63 \\
\hline & iii) Polyethylene bag & 85 & 81 & 979 & 969 & 78 & 71 \\
\hline & 2) Sun drying & & & & & & \\
\hline & i) Jute bag & 80 & 64 & 979 & 814 & 70 & 54 \\
\hline & ii) Cloth bag & 80 & 66 & 979 & 821 & 70 & 55 \\
\hline & iii) Polyethylene bag & 80 & 75 & 979 & 901 & 70 & 65 \\
\hline & $\mathrm{SE}(\mathrm{m})+$ & $\mathrm{N} / \mathrm{A}$ & 3.2 & $\mathrm{~N} / \mathrm{A}$ & 46 & $\mathrm{~N} / \mathrm{A}$ & 4 \\
\hline \multirow[t]{10}{*}{4} & $\begin{array}{l}\text { Machine-threshed ( } 400 \\
\text { rpm) }\end{array}$ & & & & & & \\
\hline & 1) Shade drying & & & & & & \\
\hline & i) Jute bag & 83 & 65 & 882 & 701 & 73 & 54 \\
\hline & ii) Cloth bag & 83 & 66 & 882 & 711 & 73 & 54 \\
\hline & iii) Polyethylene bag & 83 & 74 & 882 & 804 & 73 & 64 \\
\hline & 2) Sun drying & & & & & & \\
\hline & i) Jute bag & 78 & 67 & 912 & 712 & 68 & 55 \\
\hline & ii) Cloth bag & 78 & 68 & 912 & 720 & 68 & 55 \\
\hline & iii) Polyethylene bag & 78 & 73 & 912 & 801 & 68 & 63 \\
\hline & $\mathrm{SE}(\mathrm{m})+$ & $\mathrm{N} / \mathrm{A}$ & 3.0 & $\mathrm{~N} / \mathrm{A}$ & 42 & $\mathrm{~N} / \mathrm{A}$ & 2.8 \\
\hline \multirow[t]{10}{*}{5} & $\begin{array}{l}\text { Machine - Thre shed (500 } \\
\text { rpm) }\end{array}$ & & & & & & \\
\hline & 1) Shade drying & & & & & & \\
\hline & i) Jute bag & 78 & 61 & 814 & 702 & 68 & 51 \\
\hline & ii) Cloth bag & 78 & 63 & 814 & 704 & 68 & 52 \\
\hline & iii) Polyethylene bag & 78 & 69 & 814 & 799 & 68 & 60 \\
\hline & 2) Sun drying & & & & & & \\
\hline & i) Jute bag & 70 & 50 & 810 & 627 & 58 & 38 \\
\hline & ii) Cloth bag & 70 & 53 & 810 & 640 & 58 & 41 \\
\hline & iii) Polyethylene bag & 70 & 60 & 810 & 708 & 58 & 50 \\
\hline & $\mathrm{SE}(\mathrm{m})+$ & $\mathrm{N} / \mathrm{A}$ & 3.5 & $\mathrm{~N} / \mathrm{A}$ & 57 & $\mathrm{~N} / \mathrm{A}$ & 3 \\
\hline
\end{tabular}


Table 4. Effect of threshing, drying me thods and storage containe rs on incidence percentage of fungal flora on Mothbean during storage.

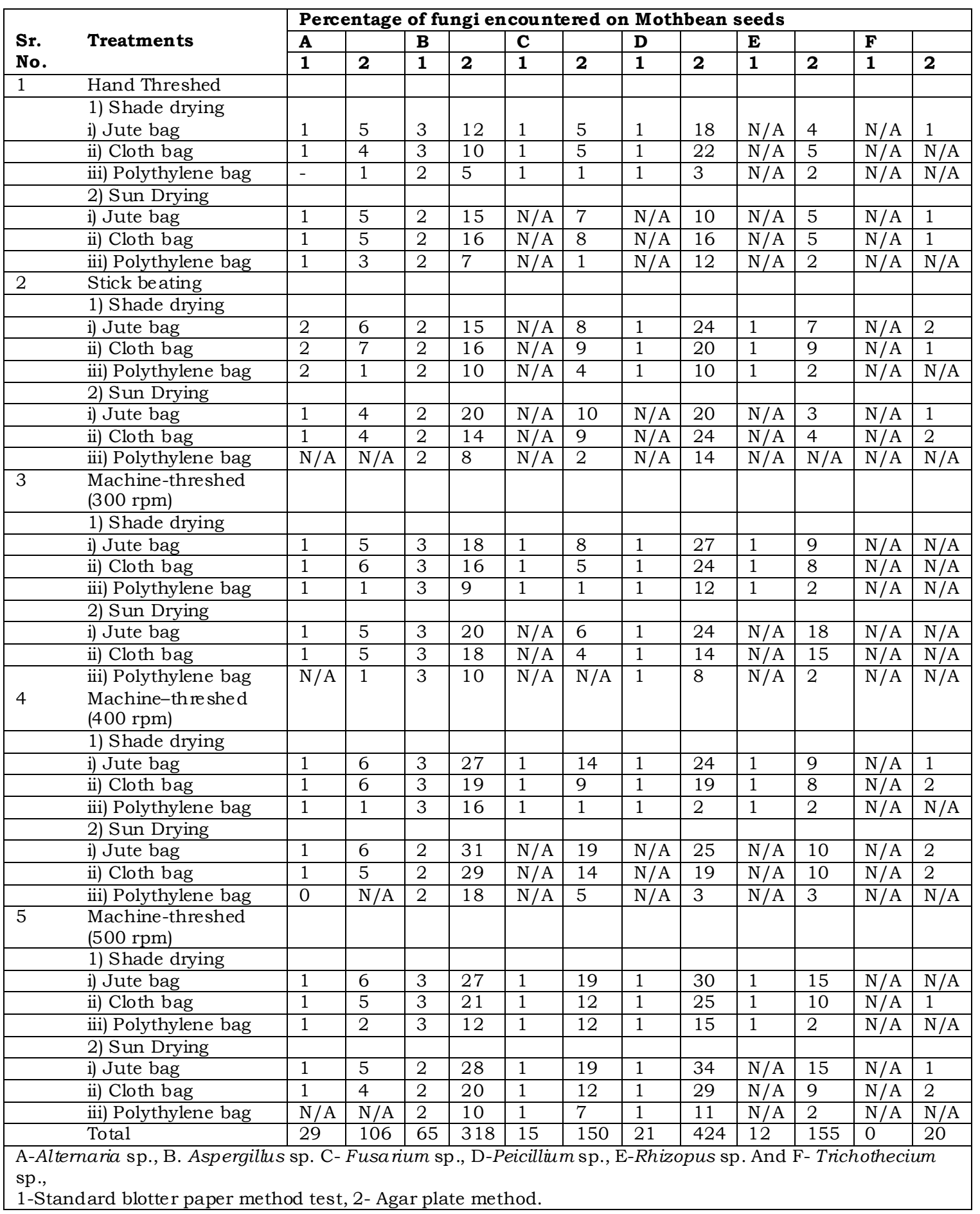

References:

Abdul Baki A. and J.D. Anderson. 1973. Vigour determination in soybean seed by multiple criteria. Crop Sci. 13: 630-633.

Charjan, S.K.U. and V.R. Gupta 1996.Impact of storage condition on fungal flora and germinability of gram seeds. J. Soils and crops 6 (2) : 136-138.

Dharmalinga m, C. and R.N. Basu. 1988. Seed quality in relation to position of seed in the pod at different maturity periods in mungean. Seed Res. 16(2) : 168172 . 
ISTA. 1976. International rules for seed testing seed sci. and technol 4: 108

ISTA. 1985. International rules ofr seed testing seed sci. and Technol $13: 299-513$

Lambat, A. Gadewar, R., Charde, P. Charjan, S., Cherian, K. and Lambat, P. 2011. Effect of Post harvest operations on seed quality of mung (Phaseolus mungo L.)In : Proc. International Conference in Agricultural Enginee ring, Chonburi, Thailand page No. C/ 13-25

Likhitkar, V.S. and S.K.U. Charjan, 1995.Impact of storage containers and period on germination of Gimelina arborea seeds during storage.In : Herbal medicines, biodiversity and conservation strategies (Ed. R.C. Rajak and M.K.Rai), international book distributors, Distributors, Deharadun : 236-241.

Ovcharov, K.E. and K.G. Kizilova 1966.Difference in seed quality and plant productivity. In: Physiological

basis of seed germination. Amerinol publishing, New Delhi pp. 140

Panse V.G. and P.V. Sukhatme. 1967. Statistical methods for agril. Workers I.C.A.R. Publication New De lhi.

Patil, V.N. and N.G. Zode. 1993. Effect of seasons and drying methods on storability of ground nut (arachis hypogaea) Seed res. Special Vol. 1: 342-247.
Philpot, R. 1976. Principles and practices of seed drying. Proceeding of Mississipi state Unive rsity Short course for seedmen $16: 23-40$.

Pullock, B.M. 1972. Effects of environment after sowing on viability. In: Viability of seeds (ed. E.H. Roberts), Chapman and hall Ltd. Landon pp. 150-171.

Saini, S.K., J.N. Singh and P.C. Gupta. 1982. Effect of threshing me thod on seed quality of soybean. Seed Res. 10 (2): 133-138.

Morrison, W.H. III and J. A. Roberts on. 1978. Effect of drying on sunflower seed oil quality and germination. J. Am oil chem.. Soc. 55 : 272-274.

Sangakkara, U.R. and W.M.T. Wanisera. 1990. Effect of post-harvest operations on seed quality of mungbean. Seed Res. 18(1) : 54-59.

Shivankar, V.J., S.N. Singh, A.A. Khan and A.S. Tomer. 1990. Effe ct of storage conditions on storability of cowpea. In International conference on seed science and technology, New Delhi.

Soesarsano, W. and I.C. Copeland. 1974. Effect of original moisture content, maturity and mechincal damage on seed and seedling vigour of beans. Agron $\mathrm{J}$. 66: 546-548.

Vanangammudi, K. 1988. Storability of soybean seeds as influenced by the variety, seed size and storage container. Seed Res. 16(1) : 81-87. 